ALICJALASAK

Jagiellonian University, Poland

e-mail: alicja.lasak@doctoral.uj.edu.pl

\title{
Revisiting the Myth of Dunkirk: Lissa Evans's Their Finest Hour and a Half
}

\begin{abstract}
The aim of the paper is to explore how the myth of Dunkirk is depicted in one of contemporary British historical novels, Lissa Evans's Their Finest Hour and a Half (2009). With reference to relevant examples from the novel, it is asked if the myth is cultivated or debunked. The article poses the question whether the novel evokes nostalgia for national unity, conveys a hopeful message about more equal opportunities for women than before the war, or reassesses history in a tragicomic manner. Three aspects addressed in Their Finest Hour and a Half are taken into consideration, namely, first, women's role in myth-making; second, soldiers' attitude towards uplifting myths surrounding the evacuation of Dunkirk; third, the impact of propaganda films on those living in the 1940s and facing the harsh reality of the war.
\end{abstract}

Keywords: Their Finest Hour and a Half, Lissa Evans, the Second World War in literature, contemporary British historical novel, myth of Dunkirk

\section{Rekonstrukcja mitu Dunkierki w powieści Lissy Evans Their Finest Hour and a Half}

Streszczenie: Celem artykułu jest zbadanie, w jaki sposób mit Dunkierki został przedstawiony w jednej ze współczesnych brytyjskich powieści historycznych - Their Finest Hour and a Half (2009) Lissy Evans. Odwołując się do konkretnych przykładów z powieści, zadajemy sobie pytanie, czy mit jest nadal kultywowany, czy też kontestowany. Artykuł stawia pytanie, czy powieść wywołuje nostalgię za jednością narodową, niesie optymistyczne przesłanie o równiejszych szansach kobiet w trakcie wojny aniżeli przed nią, czy też w sposób tragikomiczny dokonuje ponownej oceny historii. Pod uwagę brane są trzy aspekty, o których traktuje Their Finest Hour and a Half, a mianowicie, po pierwsze, rola kobiet w tworzeniu mitów; po drugie, stosunek żołnierzy do podnoszących na duchu mitów związanych z ewakuacją Dunkierki; po trzecie, wpływ filmów propagandowych na ludzi żyjących w latach 40. XX wieku i zmagających się z trudną rzeczywistością wojny.

Slowa kluczowe: Their Finest Hour and a Half, Lissa Evans, druga wojna światowa w literaturze, współczesna brytyjska powieść historyczna, mit Dunkierki 
For the sake of this article the term "myth" is not applied in one of the traditional senses, as either "a story which is not 'true' and which involves (...) supernatural beings [or] supra-human beings (...) concerned with creation"1 or "a system of hereditary stories of ancient origin which were once believed to be true in a particular cultural group" or "stories of unascertainable origin or authorship accompanying or helping to explain religious beliefs," which exploit "a god or hero, which may be of a fabulous or superhuman nature, and which may have instituted a change in the workings of the universe." 3 This article is concerned with a myth that "tends to signify a fiction, but a fiction which conveys a psychological truth," "to provide a rationale for social customs and observances"5 or a fiction which "may have instituted a change (...) in the conditions of social life." Myth is regarded as one of various possible forms of narrating the past and handling an overwhelming event that may be viewed differently from different perspectives.

This article is concerned with the enduring myth of Dunkirk and its depiction in Lissa Evans's novel. Owing to her career in media, especially in the BBC, Evans is aware of the current trends in contemporary British media, culture and literature. Since the turn of the twenty-first century, a lot of novels concerned with the Second World War have been published. ${ }^{7}$ It might be assumed that, having always been an avid reader ${ }^{8}$ passionate about war fiction, ${ }^{9}$ Evans wanted to contribute to this revival of World War Two fiction and present the events from a completely different angle. The novel's original point of view results from the fact that a national myth is explored by means of a historical novel and a propaganda film that constitutes a story within a story. It might be claimed that Their Finest Hour and a Half verges on profanity due to its challenging and ridiculing the heroic myth of Dunkirk.

Malcolm Smith lists the myth of Dunkirk as one of the "collection of smaller myths that make up the larger story of 1940." 10 This "larger story," including the myth of Dunkirk, was not created to "mislead the British [but] to make sense of their disaster, and to fight on."11 Mentioning a "disaster," Smith refers to the fact that thousands of British and French soldiers died during the Battle of Dunkirk, retreating and awaiting evacuation on the beaches. It is, however, not

${ }^{1}$ J.A. Cuddon, A Dictionary of Literary Terms and Literary Theory, $5^{\text {th }}$ ed., Chichester (West Sussex) 2013, p. 453.

2 M.H. Abrams, A Glossary of Literary Terms, $7^{\text {th }}$ ed., Boston 1999, p. 140.

${ }^{3}$ P. Childs, R. Fowler, The Routledge Dictionary of Literary Terms, $3^{\text {rd }}$ ed., New York 2006, p. 146.

${ }^{4}$ J.A. Cuddon, op. cit., p. 453.

${ }^{5}$ M.H. Abrams, op. cit., p. 170.

${ }^{6}$ P. Childs, R. Fowler, op. cit., p. 146.

7 Ian McEwan's Atonement (2001), Rachel Seiffert's The Dark Room (2001), Helen Dunmore's The Siege (2001), Andrea Levy's Small Island (2004), Sarah Waters's The Night Watch (2006), William Boyd's Restless (2006), A.L. Kennedy's Day (2007), Giles Foden's Turbulence (2007), Simon Mawer's The Glass Room (2009), to name but a few.

${ }^{8}$ lissaevans.com, https://lissaevans.com/about-lissa-evans/ (access: 15.02.2021).

${ }^{9}$ S. Davis, Interview with Lissa Evans, https://www.youtube.com/watch?v=36i9ArhIwN8 (access: 23.01.2021).

${ }^{10}$ M. Smith, Britain and 1940: History, Myth and Popular Memory, New York 2000, p. 2.

${ }^{11}$ Ibid., p. 29. 
within the scope of this article to analyse the historical circumstances and the military strategy. The events are only briefly outlined so as to draw attention to the fact that the plot unfolds against the historical backdrop.

Although wars are straight-forwardly associated with brutality, bloodshed, and suffering, contemporary British historical novels often present a nostalgic yearning for, as a history professor - Mark Connelly - states, "a golden age, a time when all were united, when Britain had a mission, when there was a great cause worthy of great sacrifices." 12 Connelly's term "golden age" used with reference to British World War Two myths can be associated with nostalgia for those times, when, despite the ongoing war, people experienced the feeling of togetherness and found a sense of purpose in endeavouring to attain a common goal of achieving victory. The term "nostalgia" is often applied with reference to the British attitudes towards World War Two: 13 "nostalgic glow is still with us in Britain (...) representations of 1940 still constitute the foundation myth of a new Britain seen to have emerged from the war." ${ }^{14}$ Even in the twenty-first century a mythological representation of the war is still to be found in novels and films. One of nostalgic literary works that is concerned with a mythologised version of the war, the Dunkirk evacuation in particular, is Lissa Evans's Their Finest Hour and a Half (2009). I have decided to analyse it since, as an example of contemporary twenty-first century British historical fiction, the novel has not been widely examined yet. It portrays new opportunities which were opened up for women in the face of World War Two, especially in the face of "fiasco [that] became a miracle of deliverance." 15 The word "fiasco" used by Mark Connelly refers to the death of many soldiers' retreating to Dunkirk, most likely, due to inadequate military decisions and a lack of an alternative plan in case of the advancement of German troops. Dunkirk casualties, including killed soldiers, civilians who sailed there in their small boats as well as traumatised survivors, are featured in Christopher Nolan's recent film Dunkirk (2017). ${ }^{16}$

As depicted in Their Finest Hour and a Half, the initial defeat led to engaging all resources in the fight and redefining women's role in wartime. Although it could be claimed that women had little to do with the evacuation from Dunkirk, Evans emphasises their role in fictionalising reality and creating uplifting myths surrounding this historical event. Women's attitude is confronted with the perspective of one of the rescued soldiers, Arthur, who looks at the world realistically and deconstructs the myth of Dunkirk. His experiences are juxtaposed with filmmakers' vision of the event and their aims. While producing the film, the evacuation from Dunkirk is used purely for propaganda purposes, which in turn exerts an impact on the public perception.

${ }_{12}$ M. Connelly, We Can Take It! Britain and the Memory of the Second World War, London-New York 2014 (first published 2004), p. 78.

13 See: ibid., M. Donnelly, Britain in the Second World War, London-New York 2005 (first published 1999), M. Smith, op. cit.

${ }^{14}$ Ibid., p. 5.

${ }_{15}$ M. Connelly, op. cit., p. 59.

${ }^{16}$ Dunkirk, dir. Ch. Nolan, Great Britain 2017. 


\section{Women as Myth-makers}

While exploring historical novels authored by British women writers, Diana Wallace contends that history has been "male-dominated" and written by "the (male) victors." 17 Yet, in general terms, women writers may turn to "myth as a way of imagining female powers and autonomy which have rarely been central to "factual' history." 18 It should be borne in mind that, in the United Kingdom, the Second World War impacted the structure of patriarchal society. More precisely, it provided women with an opportunity to make a career in occupations which had been reserved for men. The question remains whether it was their desirable career or a position taken out of necessity, a sense of duty, or as a result of an idealised vision of, for example, becoming a member of a paramilitary organisation who wears a smart uniform and rubs shoulders with handsome soldiers. Surprisingly enough, as Virginia Nicholson points out in her book containing biographical stories of British women during World War Two, "curious statistics that emerged from a Blitz survey showed that a fifth of women felt happy more often than before the war."19 It might be so because the war was viewed as "a moment of real passion, of real issues with clear-cut options." ${ }^{20}$ Women started to feel indispensable not only at home but also in factories, at railway stations and - as Their Finest Hour and a Half shows - film-making intertwined with propaganda. The novel presents how women are involved in the process of mythologising the grim reality of the war and how prone they are to believe in a mythologised version of events.

The heroine of the novel Catrin Cole seizes the chance of a lifetime when she is promoted from a menial job of a copywriter to a screenwriter because the Ministry of Information decides to employ more women in the film industry so as to appeal to the female audience more effectively. Having written a stage play and edited a number of advertisements directed at women, Catrin becomes employed in a lavish cinematic production. Since she is accepted as a member of a team of scriptwriters whose task is to compose a screenplay of a war film, the heroine is able to cultivate her passion for writing. While producing the film, she is becoming more and more engrossed in the idealised and fictionalised script she cowrites. She also fights for such a film ending that would prove that women are able to deal with the war reality and handle supposedly male tasks. As a result of both her new position and the content of the film, Catrin becomes independent from her partner, who is an aspiring artist, and changes into a self-reliant woman whose piece of work turns out to be more famous and successful than her partner's.

Another character, Sophie Smith, assumes her brother's professional responsibilities after his tragic death during the Blitz bombing. Replacing her brother, So-

${ }^{17}$ D. Wallace, The Woman's Historical Novel British Women Writers, 1900-2000, Basingstoke 2005 , p. 2.

${ }^{18}$ Ibid., p. 213.

19 V. Nicholson, Millions Like Us. Women's Lives During the Second World War, London 2012, p. 235 .

${ }^{20}$ M. Connelly, op. cit., p. 78. 
phie proves to be a competent agent of an aging actor, $\mathrm{Mr}$ Ambrose Hilliard, who used to be a famous and handsome celebrity. She exhibits entrepreneurial skills and shows great foresight, suggesting that he should appear in a film concerned with the Dunkirk evacuation. Despite not being to Mr Hilliard's liking, the role, eventually, turns out to be the best choice in the course of his career. Although he is no longer a symbol of masculinity, there are other roles that he can perform particularly convincingly to preserve his status of a film star, for instance, Uncle Frank, who accompanies two brave, young women featured in the film.

Other heroines that illustrate the female role in myth-making are the real-life prototypes of the film heroines, Rose and Lily Starling. As a female member of the team of scriptwriters, Catrin is sent on a mission to interview twin sisters who allegedly helped to evacuate about fifty soldiers stranded on the beaches of Dunkirk. They are believed to have sailed there in a small boat which they had stolen from their drunken father. During her conversation with Rose and Lily, Catrin finds out that they sailed not far from the shore and returned before their adventure even began. At this juncture the plot turns into an anticlimax and her mission could end in failure; however, the heroine knows that she is expected to return to London with a convincing and compelling story: "Catrin looked at the blank page of her notepad. She had travelled for five and a half hours for this. 'Flesh out the newspaper story,' Buckley had said. 'We're looking for a bit of colour, a few scraps of authenticity (...)."' ${ }^{21}$ Consequently, she resorts to creating a myth in the sense of "making meaning by imposing a structure on contingent experience." ${ }^{\prime 22}$ Lacking a fascinating real-life story, Catrin decides to use her imagination in order to fabricate the narrative and she composes a script about two fearless women who, against all odds, managed to sail to Dunkirk in a small boat and rescue a group of soldiers.

What forms the core of the above-mentioned myth of Dunkirk is the overemphasised role of little ships steered by civilians who carried out the evacuation that has since then been viewed as miraculous: "At the time most people were impressed by the idea of ordinary people doing their bit for their boys. It was an important gesture in a conflict that was just about to become a 'People's War,'”23 in other words, a war demanding sacrifices and heroism from every single person. Churchill, in his speech broadcast on 14 July 1940, alluded to the people's war, stating that "this is no war of chieftains, of dynasties or national ambition; it is a War of peoples and of causes." ${ }^{24}$

In the novel, two young women are thought to have sailed to Dunkirk to rescue soldiers; although they did not even leave the Isles. Their failure represents a metaphor of an ideal rescue mission that, in fact, did not succeed since thousands of soldiers died while fleeing from the enemy and awaiting a rescue mission. A few reasons why the women failed are provided, including the fear of their abusive father as well as a technical malfunction of the boat. All traces of failure

\footnotetext{
${ }^{21}$ L. Evans, Their Finest Hour and a Half, London 2009, p. 77.

22 D. Wallace, op. cit., p. 203.

${ }^{23}$ M. Connelly, op. cit., p. 72.

${ }^{24}$ M. Smith, op. cit., p. 48.
} 
are erased from the story rendered by Catrin so as to emphasise the women's courage and willingness to help as well as the crucial role of little ships. The only hindrance presented in the cinematic production is a propeller-fouling scene. The obstacle is, however, overcome by virtue of cooperation and bravery, which epitomises ordinary people engaged in the war effort.

As a result of watching the film based on their alleged heroism, the sisters summon courage to emancipate themselves from their infamous father and join a paramilitary organisation. They believe that if their cinematic counterparts are able to demonstrate mechanical skills, engage in manly activities, and contribute to the war effort, so are they. Catrin learns from their neighbour that: "'They joined the ATS. ${ }^{25}$ After the picture came out, Rose went along to the office in Southend and told them that if she could mend a boat engine, she could certainly learn how to mend an army lorry, and so could her sister, and they got signed up straight away." ${ }^{26}$ Due to a complex interrelationship between a newspaper article about their allegedly heroic deeds, Catrin's improvement on the heroines' version of events and her contribution to the screenplay, which mythologises reality by fabricating stories on the basis of true events, Rose and Lily become involuntary subjects of myth-making. Yet Catrin's decision to embellish the available story in compliance with the intention of wartime film-making as well as the sisters' response to seeing their strong-willed cinematic counterparts on the screen serve as examples of women's conscious engagement in establishing the myth of Dunkirk. The novel offers an intriguing twist since the myth influences reality, which in turn enriches the myth. To be more precise, the sisters viewed as courageous sailors of a little ship and rescuers want to become mechanics and, accordingly, they contribute to the myth of "people's war" or, as Lissa Evans puts it in an interview, "ordinary people (...) capable of doing extraordinary things in extraordinary circumstances." ${ }^{27}$

\section{Eyewitness Testimony Juxtaposed with a Myth}

It should be noted that the term "their finest hour" that appears in the title of Evans's novel refers to Winston Churchill's speech delivered in June 1940 after the retreat from Dunkirk: "there are good and reasonable hopes of final victory (...). Let us therefore brace ourselves to our duties, and so bear ourselves that, if the British Empire and its Commonwealth last for a thousand years, men will still say, "This was their finest hour." 28 The speech mythologised the British as the last hope for the war-ravaged world and reinforced the conviction that they were destined to restore peace as well as rescue people in the occupied countries. "Their finest hour" also corresponds with the title of Churchill's book published in 1949,

\footnotetext{
25 ATS stands for Auxiliary Territorial Service.

26 L. Evans, op. cit., p. 290.

27 S. Davis, op. cit., 2:18-2:23.

28 W. Churchill, Their Finest Hour, winstonchurchill.org (access: 16.02.2020).
} 
which describes the British nation as the last stronghold of resistance against the German conquest.

Determination to succeed and stoicism despite a difficult and dangerous situation, which are believed to be typical British qualities, are couched in the term "Dunkirk spirit" coined during the war. Connelly states that the myth of Dunkirk and the "Dunkirk spirit" have become crucial to the self-perception of the British since they underline and confirm the "sense of self-reliance," "coolness under tremendous pressure" and "surviving against the odds." ${ }^{29}$ One of the characters that appear in Evans's novel, Arthur, is meant to epitomise both the mythologised "coolness" and "self-resilience" since he survived fighting as a member of the British Expeditionary Force, managed to return to Britain from Dunkirk, did not suffer any wounds and, besides that, he also remains alive when his family house is bombed in an air-raid. His remarkable endurance is incompatible with his appearance since he is portrayed as a weak, short-sighted and neurotic introvert. His extreme luckiness in turn is juxtaposed with other characters' doom or inexorable fate, especially when Buckley, who has avoided enlisting, dies buried under the film props and decorations.

Juxtaposing Arthur and Buckley, Their Finest Hour and a Half combines, in Connelly's terms, "'the sacred' - the British people heroically playing their part in the titanic struggle for survival - and the 'profane' - the British people engaged in all sorts of behaviour, some of which was, perhaps, improper." ${ }^{30}$ Arthur, who represents what is "sacred" in terms of the national myth, is an active soldier and, for a few weeks, a "special military advisor"31 on the film set; whereas Buckley, who represents the "profane" aspect of the nation is depicted as an aloof and self-conceited scriptwriter who resorts to "remorseless contrivances to hold the attention" 32 of the audience. He may be good at composing gripping scripts about momentous events but is not adept at experiencing them first hand.

The congenial atmosphere on the film set and a less realistic, heroic representation of the war have a positive effect on Arthur. He feels as if he were granted a second life, recovers from trauma, falls in love, summons courage to propose, and marries Edith who was brought to the film set by a relative. Despite this coincidental and hasty marriage, it is not a typical romantic story, more of a comic one, in which, however, "the comedy is deeply shadowed." 33 The lovers are in their thirties, both of them are described as rather antisocial and introverted. Arthur spent his youth taking care of his father, who was crippled and traumatised due to his involvement in World War One, until he died and shortly after that Arthur went to another war. His father's story is case in point as far as reluctance to commemorate veterans who were severely affected by a war, either mentally or physically, is concerned. Hunt views this omission in the commemorative tradi-

${ }^{29}$ M. Connelly, op. cit., p. 54.

30 Ibid., p. 156-157.

31 L. Evans, op. cit., p. 139.

32 C. Greenland, In the Spotlight, "The Guardian" 2009, 21.03, theguardian.com (access: 11.12.2020).

33 Ibid. 
tion as "the inherent contradiction in any war memorialisation; the men who were maimed are not ones who are remembered." 34

Regarding Edith, she has started to be considered an eccentric spinster suffering from constant migraines. The making of the film is an occasion for her to marry Arthur, who is genuinely in love, whereas, for her, it is more of a marriage of convenience and definitely not love at first sight. It seems that, falling victim to the myth, she wants to impress her friends by marrying a Dunkirk survivor. Their married life is difficult at the beginning because of their sexual inexperience and paralysing shyness. Interestingly enough, it is an air raid - or, in Evans's words, "the Blitz spirit (...) that will to be ordinary, that will to do ordinary things and live an ordinary life in extraordinary times" 35 - which helps them to express their emotions and stir passion. The fact of escaping death by hair's breadth and facing the precariousness of life during the war strengthens their relationship. Although Arthur is viewed by some as a kind of hero due to what he went through, he is also aware of the fact that his being still alive is pure luck. Nonetheless, the film may serve as an example of mythologising the evacuation to make people recover from this traumatic experience and keep fighting. Despite the fact that he is expected to be a perfect soldier and hero, he is portrayed as an ordinary human being with flaws, doubts and fears.

No matter how seriously Arthur would like to take his job, he is constantly reminded that his position on location is only pro forma. It might be due to people's inclination to "reconstruct the past in ways [they] wish to reconstruct it, with little consideration for any objective truth." ${ }^{36}$ It may be assumed that a survivor's presence is needed to claim that the film is realistic; whereas neither the director nor the screenwriters are willing to consult him. The incompatibility of the script with the real conditions during the evacuation as well as soldiers' everyday reality is shyly pointed out by Arthur, who notices that the setting of the film is too pristine and perfect. The reality was much dirtier, the ships were weathered and the uniforms ill-fitting. However, none of his suggestions are adopted by the film-makers. A propaganda film cannot feature the deplorable conditions of war since it is aimed at inventing a myth. As Connelly claims, "the Dunkirk evacuation was expected to be mythological before it happened and became so as soon as it did. People were constantly told that they were living in special times." ${ }^{37}$ Consequently, the film produced by the characters must ideologically adhere to the idealised concept of this event.

The first mythologising comments were passed shortly after the Dunkirk evacuation: referring to "a British brotherhood of the sea," The Times reported that "this motley collection of ships gave a marvellous demonstration not only of trained naval tactics, but of a daring and resources native to an island race." 38 The newspaper praised the ordinary sailors' aptitude and glorified national assets.

\footnotetext{
34 N.C. Hunt, Memory, War and Trauma, Cambridge 2010, p. 178.

35 S. Davis, op. cit., 2:44-2:50.

36 N.C. Hunt, op. cit., p. 106.

37 M. Connelly, op. cit., p. 72.

38 Ibid., p. 73.
} 
At that time, an English novelist and playwright - J.B. Priestley - passed the following remark: "our grand-children, when they learn how we began this war by snatching glory out of defeat, and then swept on to victory, may also learn how the little holiday steamers made an excursion to hell and came back glorious." 39 He predicts timelessness of the myths created during World War Two and pretentiously describes Brits' ability to win against the odds. To expose the process of myth-making, such comments are ironically reflected in Evans's novel. For instance, the name of the small boat used by the Starling sisters is Redoubtable, which denotes that the enemy should be afraid of it and respect its formidable sailors. Ironically, these sailors are two young women and their drunk but goodhearted uncle.

\section{A Propaganda Film for the Masses}

Commenting on her novel, Evans refers to the home front and the concept of people's war but, surprisingly, she does not mention Dunkirk, although it lies at the heart of a story within a story in the form of a film produced by the characters. Even though the plot revolves around both those genuinely and those allegedly involved in the Dunkirk evacuation, domestic Britain in wartime seems to constitute the core of the frame story. In fact, this is how the myth of Dunkirk is brought to life, scilicet by people on the home front. Asked about her inspiration to write Their Finest Hour and a Half, Evans states: "A life-long interest in the home front from the book (...) How We Lived Then, ${ }^{40}$ the experience of being behind the scenes in television (...) and a wish to combine the two, to talk about this essentially trivial business of film-making set in an era when the world was deeply serious." 41 It should not be overlooked that Evans worked for the BBC Radio and then in television. She won BAFTA for producing and directing TV series, ${ }^{42}$ which proves her expertise on the art of film-making. Her heroine, Catrin, is primarily employed by the Ministry of Information as a screenwriter of a feature film to provide a female touch to the story about the Dunkirk evacuation, which concentrates on one of the little ships steered by two women. However, she is also responsible for writing both hilarious and pensive dialogues for Uncle Frank along with the narration for the parts of a self-confident but uncharismatic American.

A historian, Mark Donnelly points out that "film was one of the most powerful mediums of communication and therefore propaganda during the war." 43 Compared with newsreels, posters, newspaper articles or radio programmes, feature films may be regarded as "the most effective medium of cinema propaganda be-

39 Ibid., p. 76.

${ }^{40}$ N. Longmate, How We Lived Then: A History of Everyday Life During the Second World War, London 1971.

41 Interview with Lissa Evans, Red Carpet News Flash, https:/www.dailymotion.com/video/ x73k680 (access: 22.01.2021), 0:05-0:30.

42 lissaevans.com, op. cit.

${ }^{43}$ M. Donnelly, op. cit., p. 78. 
cause they could integrate messages and themes into an interesting story." 44 To provide some examples from the novel, Arthur is astonished at the differences between the cinematic production and real events, whereas the female audience is thrilled with and impressed by the gripping plot. The title of the film, the phrase Forbidden Voyage rising up out of the waves, makes it sound like a romantic adventure and an epic journey into an unknown, forbidden territory. Furthermore, it also conveys a hopeful message about what might be lying beyond the horizon.

World War Two propaganda campaigns drew on commonly held assumptions, like "the British people had a psyche and mindset that knew triumph usually came after periods of desperate peril (...) 1940 was (...) the final crowning moment in a whole history of close-run things." 45 The Dunkirk evacuation was deemed such "desperate peril" and a "close-run thing." Deep-seated beliefs were utilised by the propaganda machine, e.g.

(...) the idea that the British developed a greater sense of collective consciousness in wartime which enabled them to make sacrifices, work together and abandon narrow selfinterest in pursuit of a shared goal was continually promoted by government propaganda as a means of maintaining morale (...). The Ministry of Information and the BBC emphasised that the nation was fused together in a common cause and reassured the public that if they continued to work together, survival and eventual victory would be secured. ${ }^{46}$

The film co-written by Catrin has multiple objectives as far as its propaganda value is concerned. It is targeted at women to urge them to contribute to the war effort, which proves to be successful as illustrated by the example of Rose and Lily. It is also aimed at the American audience to encourage the USA to join the war - to achieve this objective an accidental American soldier who demonstrates neither acting skills nor charisma is cast in one of the roles. From a propagandist point of view, it does not matter that in reality there were no US citizens in Dunkirk since their country was not at war at that time. What matters is a persuasive message sent overseas. Not only the British as a nation are meant to be united but they are also bound to work together with the Americans. Finally, the film is expected to lift the nation's spirits after the Dunkirk evacuation by featuring it not as an abject failure but as a heroic act and a glorious deed.

The film is well-received by the public and proves to be morale-boosting by exerting a tremendous impact not only on the real-life prototypes of the heroines but also on Arthur and the film crew. Catrin is able to escape from the shadow of her unfaithful partner and receives a tenured post as a screenwriter owing to which she may develop her interests and pursue her career in a kind of job that was mostly performed by men in the 1940s. Although it was not physical work, this intellectual profession was deemed unladylike due to social conventions. The Starling sisters in turn opt for a more manly and physical occupation within the Auxiliary Territorial Service. Rose and Lily's self-esteem is raised so that they free themselves from their dysfunctional family. Unintentionally, the sis-

\footnotetext{
${ }^{44}$ Ibid., p. 80.

${ }^{45}$ M. Connelly, op. cit., p. 59.

${ }^{46}$ M. Donnelly, op. cit., p. 33.
} 
ters become subjects of a myth when Catrin deliberately misrepresents the facts, which leads to the sisters' conscious choice to cultivate this mythologised image of themselves. Arthur in turn becomes mentally tougher, starts believing in his courage, heroism as well as his ability to develop a romantic relationship. Yet the propaganda film does not make him willing to be sent to the front again and keep risking his life.

One could ask whether a novel about a film that peddles the myth of Dunkirk in a manipulative manner can still be relevant in the present world. In Hunt's view, one of the reasons why, in the twenty-first century, the memorialisation of World War Two is "experiencing growth in the West" is "an attempt by the nation state to unify the nation again, and to draw on unknown reserves of patriotism." 47 Evans brings into focus the fact that commemorative tradition may be misused for propaganda purposes to achieve particular political goals. In the novel, it is Arthur who can see through the propagandist messages of the film since he experienced the events personally. The masses exposed to the fabricated version of the events remain oblivious to the film's intended effect and, thus, they are prone to its manipulative techniques. Furthermore, by demonstrating the details of manipulating facts, Evans highlights artificiality in commemorating the victims of Dunkirk. The novelistic film-makers concentrate on an allegedly successful example of the rescue mission, disregarding the dead and losses caused by the defeat.

\section{Conclusions}

Owing to its imagery, irony and tragicomic traces, Their Finest Hour and a Half can be deemed, in one of the reviewers' words, "the truest and most enjoyable novel about home-front life." 48 People who did not fight on the front, mostly women but also some men, tended to create a fictional, mythical representation of the war. On the one hand, real suffering, sacrifice, and tragedies were disregarded by the created myths. On the other hand, mythologising the recent past and spreading propaganda was intended to help people muster courage and boost their hopes of winning. Yet, as depicted in the novel, both the former and the latter approach may lead to an absurd situation, in which screenwriters' vision is more poignant and convincing than a survivor's.

Against the background of the mythologised historical event, the nostalgic yearning mentioned in the introduction is reflected in the representation of women who assumed more prominent roles and started to exert a greater impact on the world around them. Furthermore, they are presented as both accidental and conscious myth-makers as well as avid cinema-goers who are thrilled to watch adventurous war films, whereas a soldier that represents the British army is depicted as a domestic sort of person, longing for normalcy and ordinariness. The novel also explores a feeling of nostalgia for national unity, which is exemplified

47 N.C. Hunt, op. cit., p. 184.

${ }^{48}$ Ch. Fowler, Their Finest Hour and a Half by Lissa Evans, "Independent" 2009, 22.03, independent.co.uk (access: 16.02.2020). 
by diverse members of the film crew that manage to attain varied goals writing a cohesive script and producing a film together.

Evans exposes common historical myths by exaggerating and ironising the manner in which they are invented and spread. Both the screenwriters' and actors' lives are portrayed in a tragicomic fashion, whereas their fate is intertwined with the script. They are aware of the propaganda value of the film as well as their devious means to satisfy political demands. It can be viewed as unethical to embellish the Dunkirk evacuation and take advantage of it solely for propaganda purposes. However, they have no second thoughts about the ethical aspect of creating a story that commemorates the events deceitfully. As a result of this misrepresentation, fallen soldiers are not properly commemorated, whereas survivors are exploited to promote further fighting. Evans's novel depicts this dissonance in a tragicomic manner by shifting attention to the home front where people are preoccupied with creating a script for a war film, although the world is being ravaged by a real war.

The novel features the myth of Dunkirk in the context of a cinematic medium of representation. The film is written and directed by those remaining on the home front for other civilians on the Isles. Thus, it displays domestic attitudes towards and projections of the evacuation based on word of mouth and newspaper articles rather than traumatised survivors' testimony. Since the representation of the myth is cinematic, it may become timeless and indelibly imprinted on the nation's memory. It can also reverberate through generations and be revisited several decades later. Touching upon British commemorative tradition of the Dunkirk evacuation, Evans exposes the perception of her contemporaries who have learned about the war mostly from literature and film. Moreover, the manipulative and political aspects of commemorating historical events by dint of cinematography are illustrated in the novel. Regardless of the passage of time, historical myths can be taken advantage of and be misused to manipulate the public. Although Evans chooses the period immediately after this historic event, the methods of exploiting historical facts for political purposes employed by the fictitious film-makers can also be utilised in the real world and in the twenty-first century.

The portrayal of the making of a film within a novel, writing a script embedded in the primary narrative and presenting characters who are at the same time screenwriters result in producing a metafictional work of literature, in which the process of creation is described self-consciously. It is this metafictional aspect of the novel that enables it to deconstruct the myth by reconstructing its production in an original and creative manner as well as by encompassing characters from different walks of life: those fighting real battles and those who recreate them by means of costumes or a typewriter.

\section{References}

\section{Primary Sources}

Evans L., Their Finest Hour and a Half, London 2009. 


\section{Secondary Sources}

Abrams M.H., A Glossary of Literary Terms, $7^{\text {th }}$ ed., Boston 1999.

Childs P., Fowler R., The Routledge Dictionary of Literary Terms, $3^{\text {rd }}$ ed., New York 2006.

Churchill W., Their Finest Hour, winstonchurchill.org (access: 16.02.2020).

Connelly M., We Can Take It! Britain and the Memory of the Second World War, London-New York 2014 (first published 2004).

Cuddon J.A., A Dictionary of Literary Terms and Literary Theory, $5^{\text {th }}$ ed., Chichester (West Sussex) 2013.

Davis S., Interview with Lissa Evans, https://www.youtube.com/watch?v=36i9ArhI wN8 (access: 23.01.2021).

Donnelly M., Britain in the Second World War, London-New York 2005 (first published 1999).

Fowler Ch., Their Finest Hour and a Half by Lissa Evans, "Independent” 2009, 22.03, independent.co.uk (access: 16.02.2020).

Greenland C., In the Spotlight, "The Guardian" 2009, 21.03, theguardian.com (access: 11.12.2020).

Hunt N.C., Memory, War and Trauma, Cambridge 2010.

Interview with Lissa Evans, Red Carpet News Flash, https:/www.dailymotion.com/ video/x73k680 (access: 22.01.2021).

lissaevans.com, https://lissaevans.com/about-lissa-evans/ (access: 15.02.2021).

Nicholson V., Millions Like Us. Women's Lives During the Second World War, London 2012.

Smith M., Britain and 1940: History, Myth and Popular Memory, New York 2000.

Wallace D., The Woman's Historical Novel British Women Writers, 1900-2000, Basingstoke 2005. 